\title{
Germainiella clandestina sp. nov. (Bacillariophyta), a new species in a little known diatom genus
}

\author{
René Le Cohu ${ }^{1,2}$, Amélie Barthès ${ }^{3}$, Joséphine Leflaive ${ }^{1,2} \&$ Loïc Ten-Hage ${ }^{1,2 *}$
}

\author{
${ }^{1}$ Université de Toulouse, INP, UPS, EcoLab (Laboratoire d'Ecologie Fonctionnelle et Environnement), 118 \\ Route de Narbonne, 31062 Toulouse, France ; *Corresponding author e-mail: \\ loic.tenhage@univ-tlse3.fr \\ ${ }^{2}$ CNRS, EcoLab, 31062 Toulouse, France \\ ${ }^{3}$ ASCONIT Consultants, 3 boulevard de Clairfont, 66350 Toulouges, France
}

\begin{abstract}
A species new to science, Germainiella clandestina, was discovered during experiments performed in an artificial freshwater channel. This species is described based on valve morphology typical for the genus Germainiella LANGE-Bertalot et Metzeltin. The major features conforming to Germainiella are the valve face as well as a part of the mantle covered by a conopeum and the presence of very small apertures corresponding to a subconopeum canal system close to the raphe fissure. These characters clearly differentiate this taxon from the two more related genera, namely Fallacia Stickle et Mann and Pseudofallacia occulta (Krasske) Y. Liu, J.P. Kociolek et Q.X. WANG. Moreover, two chloroplasts could be observed for the first time in Germainiella, providing an additional feature to separate Germainiella and both genera cited above. Some information is given on its ecology.
\end{abstract}

Key words: Diatoms, taxonomy, conopeum, subconopeum system, artificial channel

\section{INTRODUCTION}

Previously all placed within a variety of subgroups in the genus Navicula sensu lato, most of small-cell naviculoid diatoms are now classified in a large number of genera. Some of them are monotypic such as Labellicula VAN De ViJVER et LANGE-BERTALOT (VAN De Vijver et al. 2005) or Pseudofallacia Liu, Kociolek et WANG (LiU et al. 2012). Others include only a few species such as Lecohuia LANGe-Bertalot (RUMrich et al. 2000), Navigiolum Lange-Bertalot, Cavacini, Tagliaventi et Alfinito (Lange-Bertalot et al. 2003), Lacuneolimna Tudesque, Le Cohu et Lange-BertaLOT (TudesQue et al. 2015) or Veigaludwigia LANGEBertalot et Rumrich (Metzeltin \& Lange-Bertalot 2007). Till now, Germainiella included two species with G. enigmaticoides Lange-Bertalot et Metzeltin (Metzeltin et al. 2005) as generitype. It was found in several samples from Rio de la Plata (Uruguay). The second species, G. enigmatica (GERMAIn) LANGE-BERTAlot et Metzeltin, previously described under the name Navicula enigmatica by GERMAIN (1980), was discovered in a green-house of the botanical garden in Angers (France). It was recorded later in Tahiti (CosTE \& RICARD 1990), in cultured material from the Weterau plains near Frankfurt on the Main River, in Germany (WERUM \& LANGE-BERTALOT 2004) and in a river situated in Northern Bavaria (REICHARDT 2006). A third species, Germainiella clandestina sp. nov., was detected in an artificial freshwater channel where this species thrived. The aim of this article is to provide a detailed morphological description of $G$. clandestina using light microscopy, scanning and transmission electron microscopy and to give information on its ecology.

\section{Material And Methods}

Samples were collected on artificial substrates (polythene microplates) in an artificial freshwater channel. This mesocosm functioned in closed circuit and the circulating water was rich in nutrients with $71 \mathrm{mg} \cdot \mathrm{l}^{-1} \mathrm{NO} 3-\mathrm{N}$ and $207 \mu \mathrm{g} \cdot \mathrm{l}^{-1}$ PO4-P (see BARTHĖs et al. 2014). Two experiments were carried out. On the one hand, clean artificial substrates were submerged during a 14-days period. On the other hand, biofilms on artificial substrates were exposed to a drying period of one month followed by a 13-days rewetting. At the end of these periods, the biofilms were scraped with a cutter blade and used for the study of diatom community. Samples were oxidized with hydrogen peroxide, rinsed three times with deionized water and mounted in Naphrax. Light microsco- 
pe observations were conducted using an Olympus BX51 microscope with Nomarski mode (DIC) and a SC 30 digital camera. The valve number measured was 200. For scanning electron microscopy examinations, cleaned diatoms were dried onto glass coverslips attached to aluminium stubs using nail varnish and sputter-coated with a thin layer of platinum. The observations were performed using a FEGFEI Quanta 250 SEM. For transmission electronic microscopy, cleaned diatom frustules were transferred to carbon-coated grids with a micropipette and air-dried. The preparations were examined with a Hitachi HT 7600 TEM.

\section{Results}

Germainiella clandestina Le CoHU, TeN-Hage et BARTHÈs sp. nov.

Diagnosis: Frustula aspectu cingulari rectangulata. In vivis cellulis, adest unus chloroplastus in forma renis situs ex utroque latere raphis. Valvae anguste ellipticae vel lineares - ellipticae vel ample ellipticae. Longitudo : 2.8-7.6 $\mu \mathrm{m}$; latitudo : 1.3-1.9 $\mu \mathrm{m}$. Facies valvae hyalina, solum area axialis aspectabilis. In microscopo electronico : facies valvae et limbi pars tectae conopeo. Rami raphis leviter curvati cum extremis proximalibus directis ad primum latus valvae. Ordo minimorum pororum aspectabilium utrimque prope fissuram externam raphis. Striae parallelae; 50-62 in $10 \mu \mathrm{m}$, compositae alveolis. Cingulum compositum saltem quartis copulis

Holotype: PC0534079, Muséum National d'Histoire Naturelle, Laboratoire de Cryptogamie, Paris, France Isotype: BR - 4402, Belgium National Garden, Département Bryophytes \& Thallophytes, Domaine du Bouchont, Meise, Belgium

Iconotype: Fig. 6

Type locality: artificial channel inoculated with biofilms from the Garonne river

Habitat: freshwater, benthic, Garonne river

Etymology: clandestina because cryptical in natural samples from Garonne river

\section{LM morphology (Figs 1-4)}

Live cells have two diagonally offset plastids, more or less reniform (Figs 1,2). The valves are from narrowly elliptical, linear elliptical to broadly elliptical (Figs 3-4). The valve face appears hyaline with any structure other than the axial area.

\section{SEM and TEM morphology}

The frustules are rectangular in girdle view (Fig. 5). The valve face and a part of the mantle are covered by a conopeum (Fig. 6). The skeleton of this conopeum is formed by two elevated and very silicified marginal ribs and the axial sternum. These three components enclose two thin sheets faintly transparent (Fig. 7). Externally the raphe fissure is slightly curved with hardly enlarged proximal endings pointed towards the primary side of the valve. The terminal fissures are deflected to the secondary side of the valve and terminate on the mantle (Figs 6). Internally, the proximal raphe endings are clearly bended to the same side and the distal raphe endings terminate in poorly developed helictoglosse (Fig. 8). A row of very small apertures (107-128 in $10 \mu \mathrm{m}$ ) lies externally on either side of the raphe very close to it (Fig. arrows, Fig. 9) and corresponds to a subconopeum canal system (Figs 9, 10, arrows). The striae are parallel throughout and seem to have an alveolar structure (Fig. 11). They continue uninterruptedly onto the mantle where they appear as a row of rectangular open "windows" (Figs 5, 6, 10).

The cingulum consists of at least four girdle bands (Fig. 5). The valvocopula is broad; the second and the third level $(\mathrm{C} 1, \mathrm{C} 2)$ are composed of two half opposite bands which are closed at the poles of the valves, open near the valve centre and terminating in more or less cuneate endings (Fig. 5, arrow).

\section{Discussion}

Based on the presence of a conopeum, WERUM \& LANGE-Bertalot (2004) first placed Navicula enig-
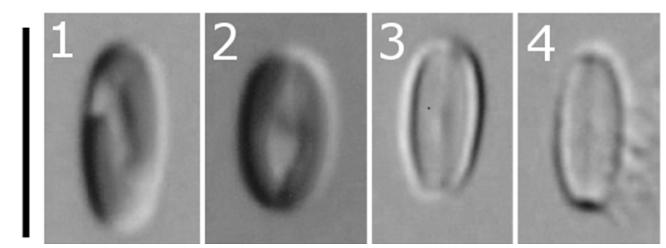

Figs 1-4. Germaniella clandestina: (1-2) live cells showing the two plastids; (3-4) light micrographs showing the frustule morphology of type population. Scale bars $10 \mu \mathrm{m}$.

Table 1. Morphological comparison of Germainiella species including G. clandestina sp. nov.

\begin{tabular}{llll}
\hline & G. clandestina sp. nov. & G. enigmaticoides & G. enigmatica \\
\hline Length $(\mu \mathrm{m})$ & $2.8-7.6$ & $6.5-11.5$ & $6-15$ \\
Width $(\mu \mathrm{m})$ & $1.3-1.9$ & $1.9-2.5$ & $2-2.5$ \\
Striae number $($ in $10 \mu \mathrm{m})$ & $50-62$ & $73-79$ & 50 \\
\hline
\end{tabular}


matica GERMAIN in the genus Fallacia. Later, describing the new genus Germainiella, LANGE-BERTALOT et Metzeltin (Meltzeltin et al. 2005) transferred this taxon to the new genus and highlighted the differences between Fallacia and Germainiella wich are closely related each other. They listed the diagnostic features of Germainiella, namely a conopeum covering the valve face and a part of the mantle, presence of canal apertures externally on either side of the raphe and the alveolar structure of the striae. However, VAN DE ViJver \& Cox (2015) have observed in Fallacia emmae VAN DE VIJVER et COX a similar striae structure as in Germainiella. Consequently, it means that the striae structure is not a discriminating feature between Fallacia and Germainiella. On the other hand, Germainiella has two diagonally offset plastids. Fallacia presents a single H-shaped chloroplast (Cox 1996). A conopeum covering the valve face as well as a part of the mantle, the presence of typical canal apertures on either side of the raphe and the morphology and the number of chloroplasts are the features distinguishing Germainiella from Fallacia. Germainiella clandestina clearly belongs to the genus Germainiella showing all the diagnostic genus features cited above. It has to be noted that the type of the cingulum organization in $G$. clandestina is similar to that observed in Encyonopsis (LE CoHu et al. 2014) and reminiscent of that found in Urosolenia (Round et al. 1990).

Apart from Fallacia, Germainiella is related to the newly created and monotypic genus Pseudofallacia based on Navicula occulta KRASSKE (LiU et al. 2012). Both genera share a few features such as two chloroplasts and a conopeum. The chloroplasts are different in the morphology and the arrangement. SEM observations provide a clear difference in the conopeum structure. In Pseudofallacia occulta (KRASSKE) Y. LiU, J.P. Kociolek et Q.X. WANG, a narrow conopeum runs along the raphe on either side. The striae are interrupted at the conopeum whereas they are completely covered by the conopeum in Germainiella. Additional
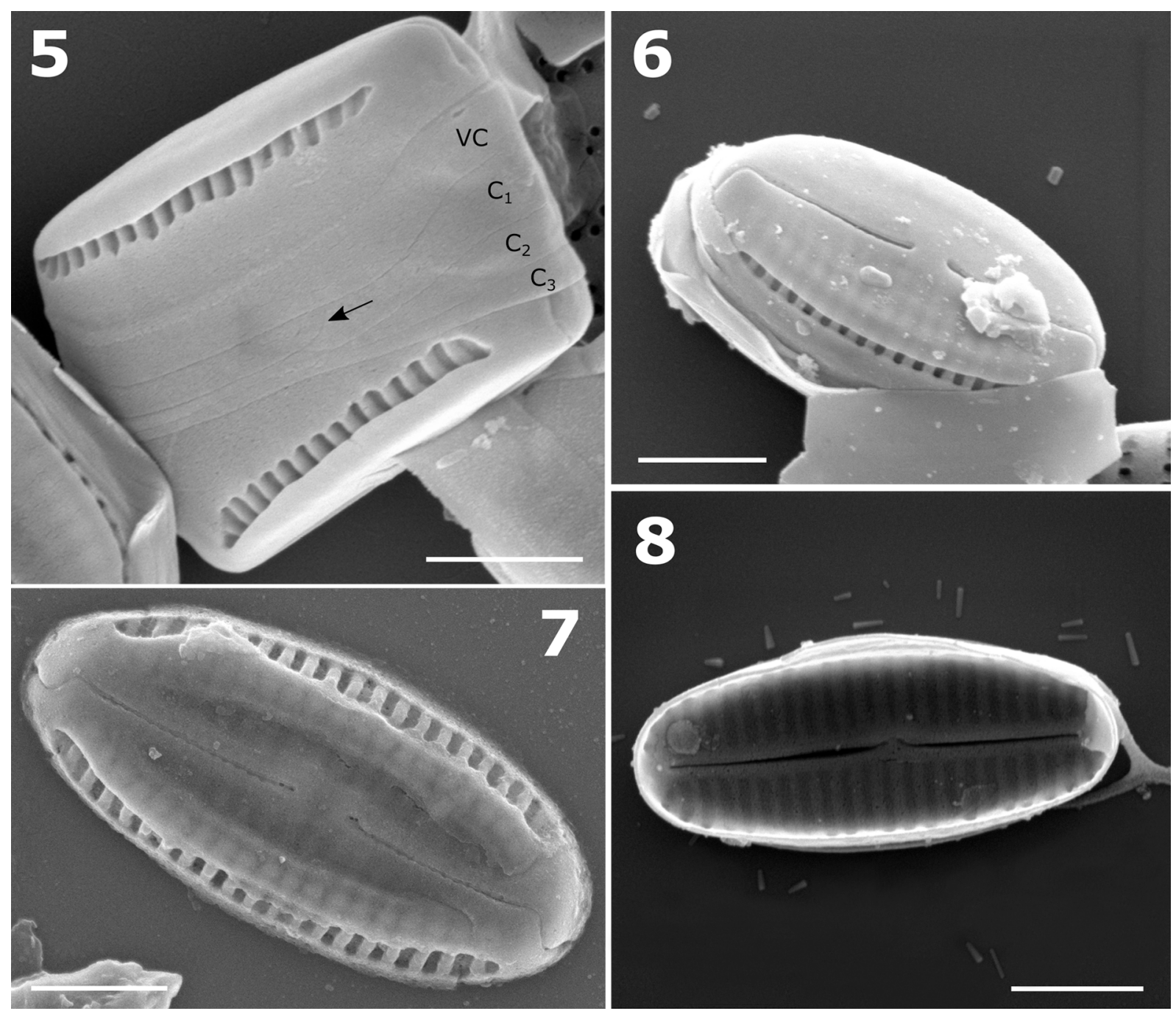

Figs 5-8. Germaniella clandestina: (5) SEM, girdle view showing the cingulum (VC: valvocopula. $\mathrm{C}_{1}, \mathrm{C}_{2}$ and $\mathrm{C}_{3}$ : copulae); (6) $\mathrm{SEM}$, external valve view showing the conopeum and the raphe fissure; (7) SEM, external view showing the skeleton composed of marginal ribs and the sternum enclosing two thin sheets hardly transparent; (8) SEM, internal view with proximal raphe ending curved to the same side. Scale bars $1 \mu \mathrm{m}$. 
differences are observed such as the presence of two elongate pores in each terminal area in Pseudofallacia. In LM, it should be noted that both genera can be easily separated by the number of the striae clearly visible in Pseudofallacia whereas they cannot be resolved in the tree species of Germainiella.

The discussion about genus delimitation and validity is related to the question of the value of each morphological feature or molecular data (WILLIAMS 2013; VAN DE VIJVER \& COX 2015). For instance, over the past 15-years, several new small genera were created from parts of the genus Navicula, including $L a$ cunicula LANGE-Bertalot et al. (2003). The latter species was rejected as an independant genus by MORALES \& LE (2003), who stated that only the presence of deep grooves next to the raphe is not sufficient to separate it from the genus Craticula Grunow. Another example is Synedra berolinensis LEMMERMAN whose the genus name has changed several times during the last twenty years but it is still very hard to know what is the scientific evidence to adopt a definitive name (WILliams 2013). VAN DE VIJVER \& COX (2015) have observed intermediate features of Fallacia emmae between Fallacia and Germainiella such as a structure of the striae but other characters can differentiate both genera (see above). Intermediate taxa, such as $F$. emmae combi- ning features of two closely related genera could help in establishing better boundaries to prevent the proliferation of new, often monotypic, genera. However the problem is always the same, namely what are the criterions to select the predominant key feature or the combination of features (morphological or molecular) which differentiate two genera.

Within the genus Germainiella, G. clandestina sp. nov. can be differenciated from $G$. enigmaticoides and $G$. enigmatica by the valve morphology (respectively pl. 54, figs 8-21, Metzeltin et al. 2005 and pl. 2, figs 14-19, Germain 1980), the striae density (Table 1), the dimensions and secondarily the slight external curvature of the raphe. It has to be noted that the very delicate pores of the conopeum observed in G. enigmaticoides (MetZeltin et al. 2005) and G. enigmatica (Fig. 30, Germain 1989) could not be detected in $G$. clandestina, even in TEM.

In the studies concerning the diatoms of the Garonne River (Eulin \& Le Cohu 1998; Ameziane et al. 2003; TEKWANI et al. 2013), G. clandestina was overlooked probably because of its rarity with environmental factors which not favoured its growth but also given its very small dimensions and its hyaline valve surface. G. clandestina seems to be associated with an environment rich in nitrogen $(71 \mathrm{mg}$.

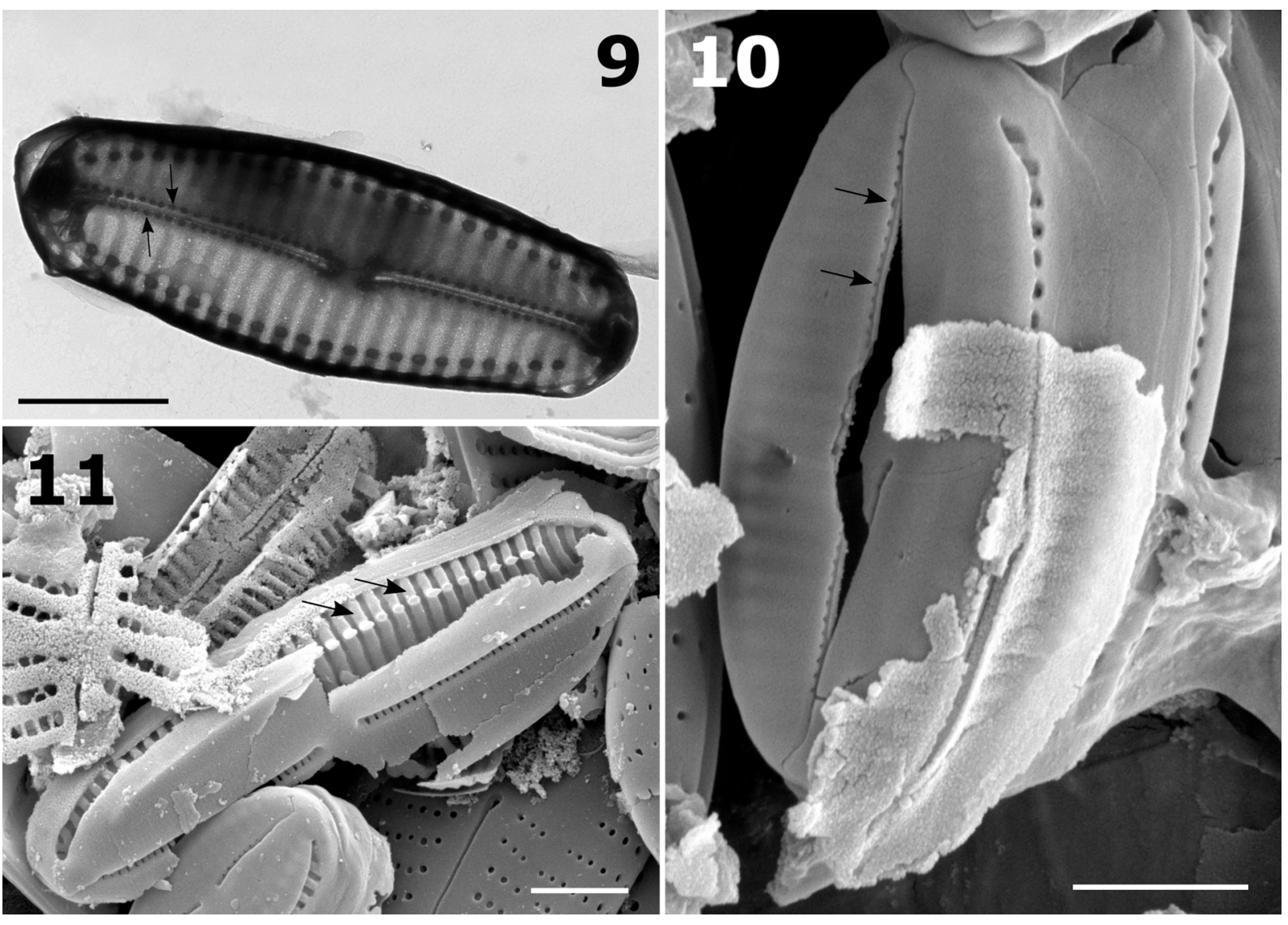

Figs 9-11. Germaniella clandestina: (9) TEM, valve view with small apertures along the raphe (arrows); (10) SEM, valve view showing the subconopeum canal system (arrows); (11) SEM, valve view with remains of the conopeum and showing the alveolar structure of the striae (arrows). Scale bars $1 \mu \mathrm{m}$. 
$\left.\mathrm{l}^{-1} \mathrm{NO}_{3}-\mathrm{N}\right)$ and phosphorus $\left(207 \mu \mathrm{g} \cdot \mathrm{l}^{-1} \mathrm{PO}_{4}-\mathrm{P}\right)$ and a temperature around $15^{\circ} \mathrm{C}$. G. clandestina as G. enigmaticoides shows some affinity for a high electrolyte content, respectively $1330 \mu \mathrm{S} . \mathrm{cm}^{-2}$ and around 600 $\mu \mathrm{S} . \mathrm{cm}^{-2}$ (Metzeltin et al. 2005). In the experiments with cleaned substrates submerged during a 14-days period, Germainiella clandestina was dominant with a relative abundance of $64 \%$. It was accompanied by Achnantidium exiguum (Grunow) CZARNeCKI (15\%), A. aff. minutissimum (KüTZING) CZARNeCKI (13\%) and Sellaphora seminulum (Grunow) D.G. MANN (8\%). In the experiments with biofilms on artificial substrates exposed to a drying phase of one month followed by a 13-days rewetting, G. clandestina was always dominant with a relative abundance of $52 \%$. It was again accompanied by $A$. exiguum (14\%), A. aff. minutissimum $(22 \%)$ and Sellaphora seminulum (12\%). In the two experiments, the relative abundance of $G$. clandestina is at least four times higher than the subdominant species. Presumably, G. clandestina has a cell division rate higher than those of the three other species, what could explain why G. clandestina is dominant.

\section{REFERENCES}

Améziane, T. ; Dauta, A. \& Le Cohu, R. (2003) : Origin and transport of phytoplankton in a large river: the Garonne, France. - Archiv. Hydrobiol. 156: 385-404.

Barthès, A.; Ten-Hage, L.; Lamy, A.; Rols, J.L. \& Leflaive, J. (2014): Resilience of aggregated microbial communities subjected to drought: small-scale studies. - Microb. Ecol. 70: 9-20.

Coste, L. \& Ricard, M. (1990). Diatomées continentales des îles de Tahiti et de Moorea (Polynésie Française). In : RicARD M \& Coste M. Ouvrage dédié à la mémoire du Professeur H. Germain (1903-1989). - pp. 33-62, Koeltz Scientific Books, Koegnistein - Germany.

Cox, E.J. (1996). Identification of freshwater diatoms from live material - 158 pp., Chapman \& Hall, London.

Eulin, A. \& Le CoHU, R. (1998). Epilithic diatom communities during the colonization of artificial substrates in the river Garonne (France): comparison with the natural communities. - Arch. Hydrobiol. 143: 79-106.

Germain, H. (1980) : Trois nouvelles diatomées dans le bassin d'une serre à Angers (France). -Cryptogamie, Algologie 1: 19-27.

Germain, H. (1989) : Dissemblance entre les côtés externes et internes de la valve observée en microscopie électronique à balayage chez quelques diatomées pennées - Cryptogamie, Algologie 10: 173-179.

Lange-Bertalot, H.; Cavacini, P.; Tagliaventi, N. \& AlfiNITO, S. (2003): Diatoms of Sardinia. - Iconographia diatomologica $12: 1-438$

Le Cohu, R. ; Gassiole, G. \& Coste, M. (2014): Three new species of Cymbellales (Bacillariophyceae) from Reunion Island. - Phytotaxa 156: 117-132.

Liu, Y.; Kociolek, J.P.; FAn, Y. \& Wang, Q. (2012): Pseudofallacia gen. nov., a new freshwater diatom (Baccilariophyceae) genus based on Navicula occulta Krasske. - Phycologia 51: 620-626.
Metzeltin, D. ; Lange-Bertalot, H. \& Garcia-Rodriguez, F. (2005) : Diatoms of Uruguay compared with other taxa from South America and elsewhere. - Iconographia Diatomologica 15: 1-736.

Metzeltin, D. \& Lange-Bertalot, H. (2007): Tropical diatoms of South Africa II - Special remarks on biogeographic disjunction. - Iconographia Diatomologica 18: $1-867$.

Morales, E.A. \& Le, M. (2005) : The taxonomy of the diatom Lacunicola sadinensis Lange-Bertalot, Cavacini, Tagliaventi \& Alfinito and its relationship with the genus Craticula Grunow (Bacillariophyceae). Proceeding of the Academy of Natural Sciences of Philadelphia 154: 155-161.

ReichaRd, E. (2006). Bemerkenswerte Diatomeenfunde aus Bayern $\mathrm{V}^{1}$ - Neue und seltene Arten aus der Scharzachklamm - Berichte der Bayerischen Botanischen Gesellschaft 76: 41-51.

Round, F.E.; Crawford, R.M. \& Mann, D. (1990): The diatoms - Biology \& Morphology of the genera. - 747 pp., Cambridge University Press, Cambridge, Reprinted 2000.

Rumrich, U.; Lange-Bertalot, H. \& Rumrich, M. (2000): Diatomeen der Anden - von Venezuela bis Patagonien/Feuerland. - Iconographia Diatomologica 9: $1-649$.

Tekwani, N. ; Majdi, N. ; Mialet, B.; Tornes, E. ; UrreaClos, G. ; Buffan-Dubau, E.; Sabater, S. \& Tackx, M. (2013): Contribution of epilithic diatoms to benthic-pelagic coupling in a temperate river. - Aquat. Microb. Ecol. 69: 47-67.

Tudesque, L.; Le Cohu, R.; Coste, M. \& Lange-Bertalot, H. (2015) : Lacuneolimna gen. nov., Lacuneolimna zalokariae comb. nov. and Lacuneolimna novagallia spec. nov. (Bacillariophyceae) from the French Guiana diatom freshwater flora. - Phytotaxa 231: 19-30.

Van de Vijver, B.; Frenot, Y.; Beyens, L. \& Lange-BerTALOT, H. (2005) : Labellicula, a new diatom genus (Baccilariophyta) from Ile de la Possession (Crozet Archipelago, Subantarctica). - Cryptogamie, Algologie 26: $125-133$.

VAn DE ViJver, B. \& Cox, E.J. (2015): Fallacia emmae sp. nov., a new soil inhabiting diatom species from subantarctic region. - Cryptogamie, Algologie 36: 245-254.

Werum, M. \& Lange-Bertalot, H. (2004): Diatoms in spring from Central Europa and elsewhere under the influence of hydrogeology and anthropogenic impacts. - Iconographia Diatomologica 13: 1-417.

Williams, D.M. (2013): Why is Synedra berolinensis so hard to classify? More on monotypic taxa. - Phytotaxa 127: 113-127.

(C) Czech Phycological Society (2016)

Received August 26, 2015

Accepted February 29, 2016 